\title{
Promoting Fast Tour and Travel Using a Marketing Booklet
}

\author{
Effendi, C. D \\ English Department, Faculty of Letters, Petra Christian University, Siwalankerto 121-131, Surabaya \\ 60236, East Java, INDONESIA \\ E-mail: 1 11413021@john.petra.ac.id
}

\begin{abstract}
Fast tour and travel is a travel agency located in Jalan Raya Lontar 259B, Surabaya, which has a unique target market who are foreigners. It hardly find their own target market and usually depend on overseas travel agencies. Therefore, a marketing booklet is an effective promotional tool that can help Fast Tour and Travel to get more foreign customers because this marketing booklet will be distributed in Universities in Surabaya which have student exchange program. This marketing booklet consists of table of content, company profile, explore Surabaya (Surabaya tourist destinations), some favourite destinations near Surabaya (Bromo, Malang, and Madura), and contact information (contact us). By having this marketing booklet, Fast Tour and Travel can get their main target market.
\end{abstract}

Keyword: promotion, promotional tool, marketing booklet.

\section{INTRODUCTION}

There are some business communication problems I found during my internship in Fast Tour and Travel. The first problem I found was they has a simple company profile. There is no explanation about their company except they are a travel agency. In their website, there is only information about what they do, where to contact, and the packaged without prices. If the customers want to know more about the tour packages details, price, they have to contact Fast Tour and Travel directly. Therefore, my suggestion is that Fast Tour and Travel must update their company profile in their promotional tools, website, so that their customers will know more about them through their promotional tools.

The second problem I found in Fast Tour and Travel is the way they promote their service. They already used social media as one of their promotional tools, such as Facebook, Instagram, and website. However, the one who handle it is Mr. Budi, the owner, which I think it is not supposed to be done by him and that caused they cannot promote their packages periodically. The solution that I give to them is to make a specific schedule to promote their service or packages in their social media periodically, for example three times a week. Therefore their customers can know the existence of Fast tour and Travel. They do not have to post about their service or event, but they can post everything which related to travelling, for example travel packing hack, tips travel with baby, etc.

The third problem I found in Fast Tour and Travel was the way they promote their package to their target market, foreigners. However, it usually depends on overseas travel agencies. Foreigners who want to come to Indonesia will go to travel agent and they will give its customer to Fast Tour and Travel. Fast Tour and Travel will give the tour package to them as well as the fixed price, however, they will charge more money for themselves which is more expensive. For example, Fast Tour and Travel gives East Java tour to foreigners IDR 3 Million Rupiah, but the overseas travel agent might give their customers IDR 6 Million Rupiah. In this 
case, Fast Tour actually can get higher profit if they sell it directly to the foreign customers rather than sell it through overseas travel agencies.

For this problem, I suggest Fast Tour and Travel make a marketing booklet and put it in some Universities in Surabaya which have student exchange program. Therefore, it can help Fast Tour and Travel get their main target market easier and not depend on overseas travel agent. For example, in Petra Christian University, especially the English Department, which almost have exchange program every semester and the student exchange can be Fast Tour and Travel's potential target market. This marketing booklet will help Fast Tour and Travel to promote their packages and tour packages to the foreign students in Surabaya. This marketing booklet will explain a little bit about certain places in Surabaya and around Surabaya.

The problem that I would like to solve is the third problem because I think that the problem is the most important one at Fast Tour and Travel. The fact that they hardly find their own target market should be fixed so that they do not have to depend on overseas travel agencies. That is why I think a marketing booklet is the best solution for them because this marketing booklet will be distributed in Universities in Surabaya which have student exchange program.

There are some benefits for Fast Tour and Travel from my Business Communication Project. First, Fast Tour and Travel will get a promotional tool that can promote their package to their customers who are foreigners. By reading this marketing booklet, the customers can see what kind of product and service that Fast Tour and Travel provides.

Second benefit is for Fast Tour and Travel employee, when there is a company which want them to send the booklet, they usually send them the itinerary rather than explanation about the place. That's make the company cannot choose another places besides follow the itinerary that Fast Tour and Travel give. However, if they send this marketing booklet, then they can choose their place by themselves and Fast Tour and Travel can arrange the place so that the customer will enjoy the trip.

Promotional, according to Kazmi \& Batra, "is the communication arm of marketing and includes marketing activities, used to inform, persuade and remind the target market about an organization, its products, service, and other activities to build a favourable image" (2008, p. 8). Another source stated that "promotion is an activities that communicate the product or service and its merits to target customers and persuade them to buy" (Kotler, Wong, Saunders, Amstrong, 2005).

Marketing according to American Marketing Association (AMA), "Marketing is the activity, set of institutions, and processes for creating, communicating, delivering, and exchanging offerings that have value for customers, clients, partners, and society at large". Another source, Philip Kotler, also stated in his book that "Marketing is the science and art of exploring, creating, and delivering value to satisfy the needs of a target market at a profit" (Kotler \& Keller, 2011, p. 5)

Booklet according to Oxford dictionary, "Booklet is a small thin book with a paper cover that contains information about a particular subject."

From this definition, I can conclude that marketing booklet is a promotional tool which looks like a small book to promote company's product, to build awareness to society, and to deliver value to company's target market to make a profit.

John Kemm and Ann Close (1995), in their book, Health Promotion Theory and Practice, stated that booklet have two advantages, it can be learned all the time because the design looks like a book and contains more relatively information compared with posters.

There are some principles to make a marketing booklet effectively, useful, important, and relevant information. First, always remember that this booklet's purpose is to sell the place not only giving information about the place. Selling the place means we give the right amount 
of information to grab the reader's attention and to persuade them to buy the product or service. Giving information about the place means we describe everything in that place to the readers' without hoping that they will buy the company's product or service. Val Adkins stated in his book, Creating Brochures and Booklets, "Do not use more words than you must, but use words that will grab your readers' attention" $(1994$, p.6)

Second, make the marketing booklet attractive so that the readers want to read the marketing booklet. Give a different touch every page but not far from company's brand, thus the readers' might be interested to read and aims to keep reading. White space or empty space in every page to give pauses to readers while they are reading it. (Arsyad, 2009, p.85)

\section{METHODS}

During my internship in Fast Tour and Travel, I found out that they have three problems and I choose to solve the third problem which is the way they promote their package to their target market, foreigners. I decided to make a marketing booklet to solve their problem. Actually, they have their own marketing booklet, but theirs consists of itinerary rather than explanations of the place. That is why I think this marketing booklet might help them for both foreign and local companies.

As soon as my BCFP proposal was approved by the Board of Examiners, I started to list the place that might be interesting for foreigners. Then I came to my boss and asked for his advice about the place that I chose. Some places that I chose are not suitable for them, so I had to remove it and they approved 9 places in Surabaya to be in this marketing booklet.

Afterwards, I started making the content by watching people's vlog, blog, and their website. Then I when I had time, I went to that place and took some pictures of that place. When I made the content in the office, therefore, I could ask my boss about the content that I made.

\section{FINDING AND DISCUSSIONS}

The product that I made for my BCFP is a marketing booklet for Fast Tour and Travel. The purpose of this marketing booklet is to promote Fast Tour and Travel products and services, especially East Java Tours to their target market, foreigners. Therefore, in this marketing booklet I put some places which can attract foreigners to come to Indonesia using our services. This marketing booklet consist of five sections, such as table of content, company profile, the products and services, the tours destinations in Surabaya, and some favourite destinations near Surabaya.

In the front cover, I choose the night picture of Majapahit hotel because I want to show the elegant side of this booklet and I choose the night picture of Majapahit hotel because I want to show the elegant side of this booklet and I choose this hotel because this hotel is one of the famous historic place in Surabaya. I put the rectangular frame in cover to make it just like the template of Fast Tour and Travel when posting a picture in their social media.

After the front cover, I put my name, EBC and PCU so that the readers know that I made this marketing booklet for my final project.

In the next page is table of content. In this section, I put the list of the sections of the booklet to help the readers find what they want to read.

After the table of content is Fast Tour and Travel company profile. In this page, there is a brief information about Fast Tour and Travel, for example what they provides, what can they do, and what they will do to their customers. 
The next page is only the text of "EXPLORE SURABAYA". I only put this text to separate the sections between Surabaya destinations and favourite destinations around Surabaya section.

The next sections of this page is nine place of Surabaya destinations, I explain the place itself and the story of the place.

The next page, I only put a text "the journey has not finished yet" to make be the end of Surabaya destinations sections.

The two pages after that page, I put the blue and white color in gradation with text written "Favourite destinations near Surabaya" and "Bromo Mountain, Malang, Madura". I made this to show the transition between the Surabaya and outside Surabaya. This is also a heading of the sections.

Another two pages is about Bromo Mountain. The reason why I use to pages to talk about Bromo Mountain is because it is the most favourite place to visit by both local and international customers. That is why I use two pages to show that this is different from the other places. Another reason why I use two pages is because, if only use one page, the scenery of Bromo Mountain cannot be shown in this booklet. Madura.

Another two pages is about another places near Surabaya which are Malang and

The last page is Fast Tour and Travel contact to help the readers find them.

\section{CONCLUSION AND SUGGESTION}

I did my internship in Fast Tour and Travel. This travel agency's uniqueness is that their target market is foreign people. Fast Tour and Travel has some problems, some of which is that cannot reach their target market easily. I believe this problem can be solved by marketing booklet because it will be put in some universities in Surabaya which have exchange program, especially the English Department, Petra Christian University. This marketing booklet will help Fast Tour and Travel to promote their service and tour packages. This marketing booklet will explain certain places in Surabaya and near Surabaya. It will consists of five sections, such as table of content, company profile, the products and services, the tours destinations in Surabaya, and some favourite destinations near Surabaya.

There are some benefits that the travel agency get from this marketing booklet. First, Fast Tour and Travel will get a promotional tool which can promote their package to their main customers, foreigners, by distribute the marketing booklet in universities in Surabaya which have student exchange program. Second, this marketing booklet can help their employee when there is a company which want them to send their packages. Rather than give the company an itinerary, it is better to give them a marketing booklet so that the company can choose their destination by themselves.

My suggestion for the next EBC students who want to do Business Communication Final Project is that it is better for them to explain first to the company about what they are going to do for the $\mathrm{BCP}$, to make sure that the project can really help the company. Secondly, I think it is better to do the project in the company so that the company can see the progress of this project and it will fulfil what the company wants and needs.

\section{BIBLIOGRAPHY}

Adkins, V. (1994). Creating Brochures and Booklets. In V. Adkins, Creating Brochures and Booklets (1 ed.). North Light Books. 
advertising. (n.d.). Retrieved from www.businessdictionary.com Arsyad, A. (2009). Media Pembelajaran. In A. Arsyad, Media Pembelajaran. Jakarta: PT Raja Grafindo Permai.

Hornby, A. S. (2010). Oxford Advanced Learner's Dictionary. New York: Oxford University Press.

John Kemm, A. C. (1995). In Health Promotion Theory and Practice. Houndmills: Macmillan Press LTD.

Kaptan, S. (2001). Advertising: New Concepts. In S. Kaptan, Advertising: New Concepts (1 ed., p. 8). New Delhi: Sarup and Sons.

Philip Kotler, K. L. (2011). Marketing Management. In K. L. Philip Kotler, Marketing Management (14 ed., p. 5). Upper Saddle River, New Jersey: Prentice Hall.

Tunjungan Plaza. (n.d.). About us. Retrieved from www.tunjunganplaza.com 